\title{
TRANSFORMASI NITROGEN DI LAUT
}

\author{
Oleh \\ Hanny Meirinawati ${ }^{1)}$
}

\begin{abstract}
NITROGENTRANSFORMATIONIN MARINE ENVIRONMENT. Nitrogen transformations are undertaken by marine organisms as part of their metabolisms, either to obtain nitrogen to synthesize structural components or to gain energy for their growth. Nitrogen can stimulate primer productivity in an aquatic ecosystem. Increasing human activities can cause the increase of the number of nitrogen in the ocean. The increased input of nitrogen which is often accompanied by oxygen limitation has a strong negative effect on benthic metabolism and nitrogen mineralization. The ocean's nitrogen cycle is driven by complex microbial transformations, including nitrogen fixation, assimilation, nitrification, anammox (anaerobic ammonium oxidation) and denitrification.
\end{abstract}

\section{PENDAHULUAN}

Nitrogen memiliki bentuk transformasi kimia yang unik, lebih banyak dari unsur-unsur lain. Bentuk transformasi nitrogen yang terjadi adalah berupa senyawa atau ion yang bermanfaat bagi makhluk hidup. Hampir semua transformasi ini dilakukan oleh organisme laut sebagai bagian dari metabolisme mereka, baik digunakan untuk mensintesis komponen struktural maupun untuk mendapatkan energi untuk pertumbuhan (Gruber, 2008).

Nitrogen berperan sentral sebagai elemen pembatas untuk produktivitas biologi dalam biogeokimia laut. Selain itu, nitrogen memberikan pengaruh yang signifikan pada siklus dari banyak unsur lainnya misalnya karbon dan fosfor (Gambar 1).
Siklus nitrogen di bumi telah berkembang selama tiga miliar tahun melalui gabungan proses biogeokimia dan proses mikroba melalui masukan alami yang menjaga siklus nitrogen di lautan dalam keseimbangan (Canfield et al., 2010). Pada Gambar 1 menunjukkan bahwa fiksasi fotosintesis karbon menjadi bahan organik oleh fitoplankton laut, terjadi di zona eufotik. Hal yang sama terjadi pada unsur hara seperti nitrogen, fosfor, dan zat besi yang mengalami remineralisasi dan asimilasi. Sebagian besar bahan organik dihasilkan baik melalui respirasi atau remineralisasi di zona eufotik, dan sebagian kecil diekspor ke zona aphotic. Perubahan bahan organik menjadi bahan anorganik, kemudian dibawa ke zona eufotik oleh sirkulasi laut dan pencampuran yang dapat mendorong pertumbuhan baru (Gruber, 2008).

\footnotetext{
${ }^{1)}$ Kelompok Penelitian Oseanografi dan Perubahan Iklim Global, Pusat Penelitian Oseanografi-LIPI
} 


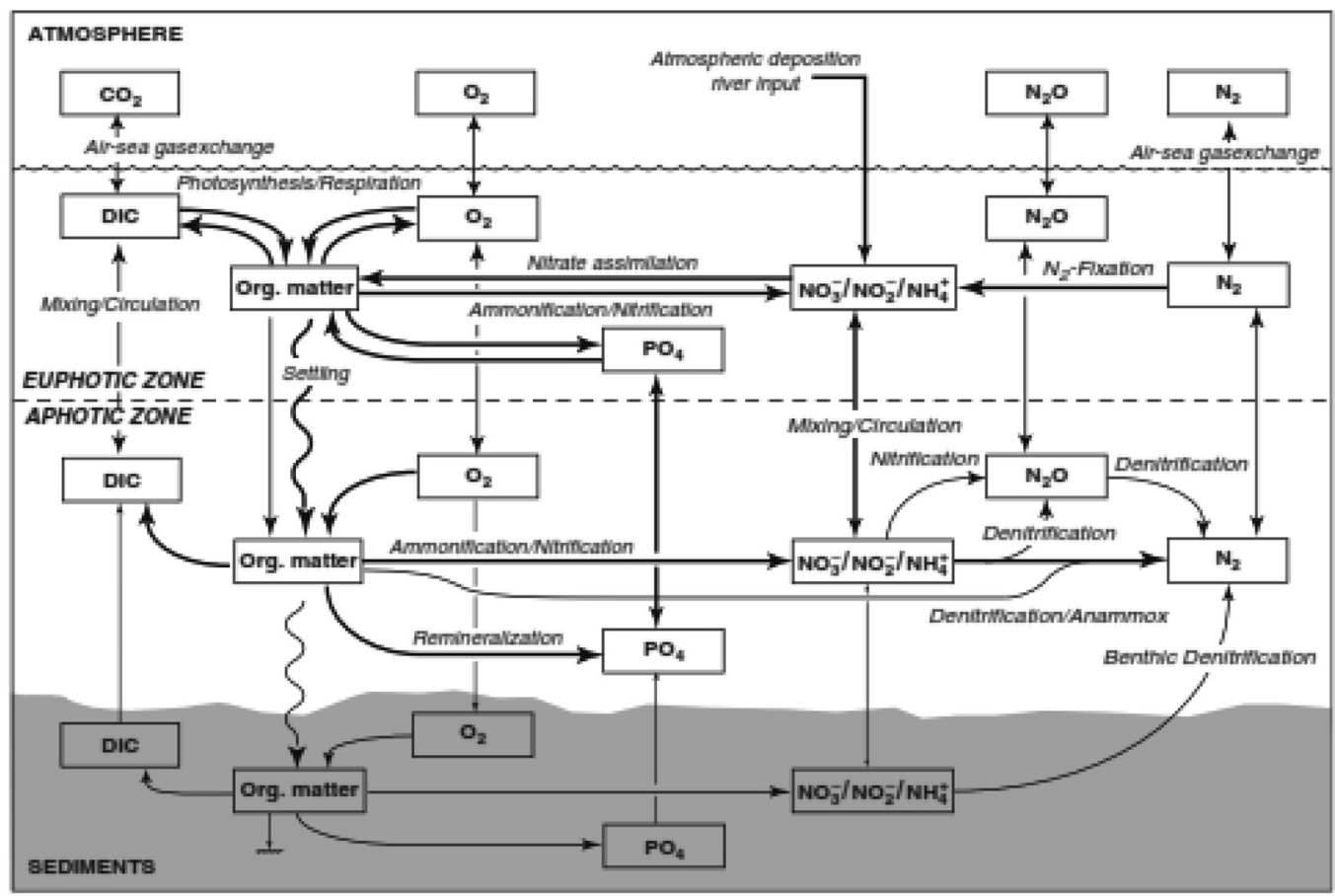

Gambar 1. Skema siklus nitrogen di laut terkait dengan siklus oksigen, fosfor, dan karbon (Gruber, 2008).

Produksi primer di lautan sebagian besar didorong oleh ketersediaan senyawa nitrogen anorganik dan organik. Sistem pesisir menerima nutrien dari daur ulang bahan organik, melalui masukan sungai, deposisi atmosfer, transportasi nutrien dari laut terbuka, dan sebagian kecil dari fiksasi $\mathrm{N}_{2}$ (Cugier et al, 2005; Lancelot et al, 2007). Kenaikan jumlah nitrogen didorong oleh semakin banyaknya produksi pupuk nitrogen), sehingga terjadi perubahan tidak hanya ekosistem darat dan air tawar, tetapi juga ekosistem pesisir dan laut terbuka (Beman et al., 2005; Duce et al, 2008; Galloway et al., 2004).

Proses transformasi $\mathrm{N}$ banyak dipengaruhi oleh manusia (Gambar 2).
Meningkatnya emisi nitrogen dan fosfor (P) ke laut, darat dan atmosfer dapat menyebabkan eutrofikasi (Voss, 2011). Frekuensi masukan oksigen yang tinggi dalam kondisi oksigen terbatas memiliki efek negatif yang kuat pada metabolisme bentik dan mineralisasi nitrogen (Karlson et al., 2007). Siklus nitrogen laut dipengaruhi oleh transformasi mikroba kompleks, termasuk fiksasi nitrogen, asimilasi, nitrifikasi, anammox (anaerobic ammonium oxidation, dan denitrifikasi. Lautan di dunia, termasuk daerah pesisir dan daerah upwelling, merupakan sumber utama yang berkontribusi sekitar 30 persen untuk jumlah $\mathrm{N}_{2} \mathrm{O}$ atmosfer (Voss et al., 2013). 


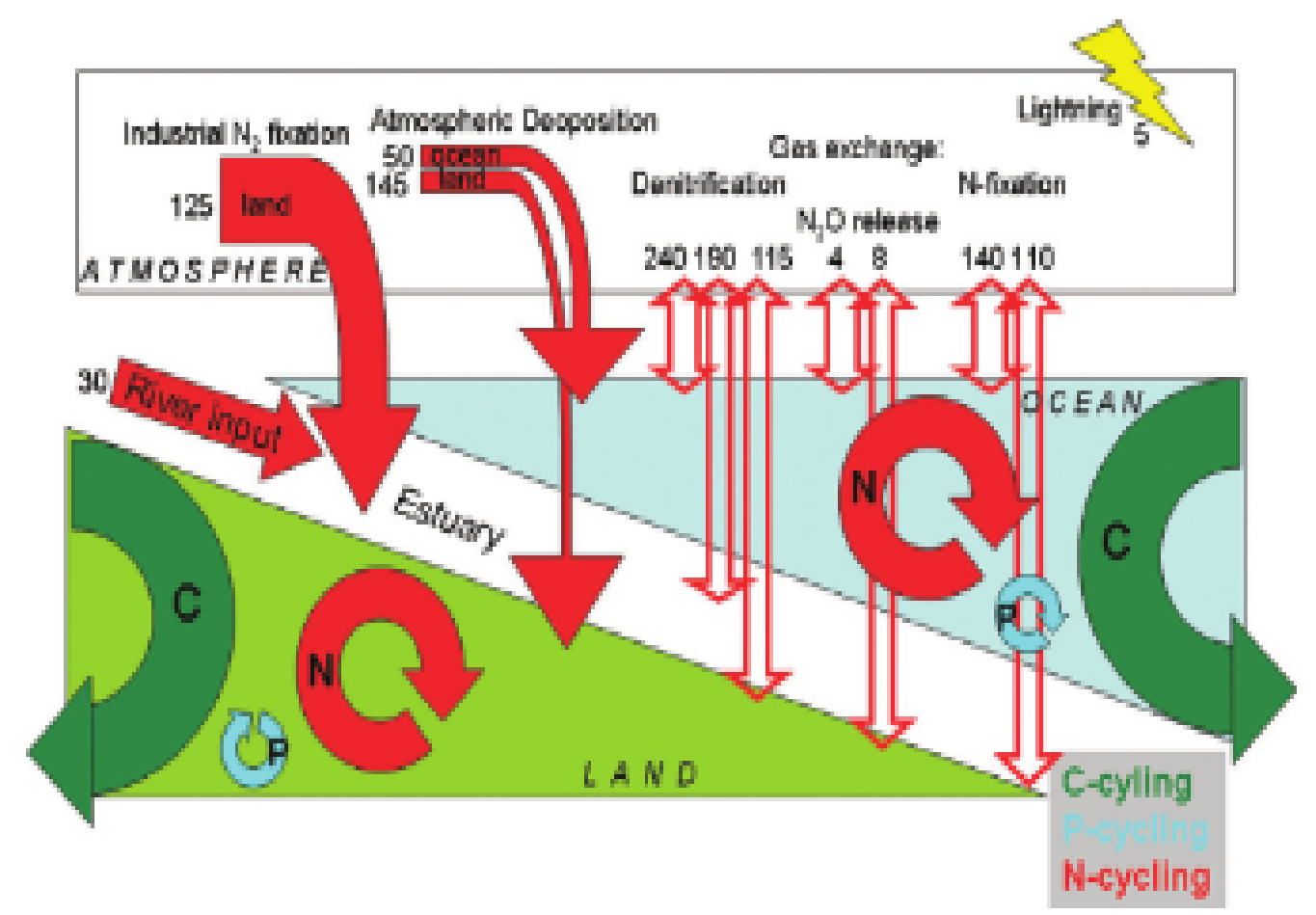

Gambar 2. Skema keterkaitan daratan dan lautan dari siklus nitrogen (Voss, 2011)

\section{NITROGEN DI LAUT}

\section{Bentuk Nitrogen}

Nitrogen merupakan elemen penting untuk semua bentuk kehidupan. Nitrogen pada air laut sebagian besar (lebih dari 95\%) berbentuk gas $\mathrm{N}_{2}$ terlarut tidak reaktif dan tidak dapat digunakan oleh sebagian besar spesies, disebabkan karena kekuatan besar dari ikatan rangkap tiga antara dua atom nitrogen. Sisanya berada dalam bentuk nitrogen reaktif $(\mathrm{Nr})$, seperti nitrat, amonia dan senyawa organik terlarut. Proses fiksasi $\mathrm{N}_{2}$ yang melibatkan mikroba tertentu dapat mengkonversi $\mathrm{N}_{2}$ menjadi senyawa yang lebih reaktif (Voss et al., 2013). Nitrogen dalam jumlah yang besar terjadi secara alami melalui oksidasi. Transformasi redoks antara oksidasi ini adalah gambaran penting dari siklus nitrogen laut (Libes, 2009; Voss et al., 2013).

Bentuk nitrogen sebagian besar dikendalikan oleh reaksi redoks yang dimediasi oleh fitoplankton, bakteri, dan mikroba. Sebagai hasil dari transformasi ini, nitrogen hadir di banyak reaksi oksidasi seperti yang tercantum pada Tabel 1. Ada dua bentuk kelarutan nitrogen di air laut yaitu DIN (Dissolved Inorganic Nitrogen ) dan DON (Dissolved Organic Nitrogen). DIN merupakan ion nitrogen anorganik terlarut, misalnya $\mathrm{NO}_{3}^{-}, \mathrm{NO}_{2}^{-}$, dan $\mathrm{NH}_{4}^{+}$. DIN dihasilkan dari proses remineralisasi nitrogen organik. 
Tabel 1.Bentuk Nitrogen di Laut (Libes, 2009).

\begin{tabular}{|l|l|l|}
\hline Bentuk & Rumus Molekuler & Bilangan Oksidasi \\
\hline Ion Nitrat & $\mathrm{NO}_{3}^{-}$ & $+\mathrm{V}$ \\
\hline Gas Nitrogen dioksida & $\mathrm{NO}_{2}$ & $+\mathrm{IV}$ \\
\hline Ion Nitrit & $\mathrm{NO}_{2}^{-}$ & $+\mathrm{III}$ \\
\hline Gas Nitrogen Monoksida & $\mathrm{NO}$ & $+\mathrm{II}$ \\
\hline Gas Dinitrogen Oksida & $\mathrm{N}_{2} \mathrm{O}$ & $+\mathrm{I}$ \\
\hline Gas Nitrogen & $\mathrm{N}_{2}$ & 0 \\
\hline Gas Amonia & $\mathrm{NH}_{3}$ & $-\mathrm{III}$ \\
\hline Ion Amonium & $\mathrm{NH}_{4}^{+}$ & $-\mathrm{III}$ \\
\hline Amina Organik & $\mathrm{RNH}_{2}$ & $-\mathrm{III}$ \\
\hline
\end{tabular}

Sebagian besar nitrogen terlarut dalam air laut berada dalam bentuk DON (Dissolved Organic Nitrogen), kecuali di perairan laut dalam yang memiliki konsentrasi nitrat sangat tinggi. Bilangan oksidasi nitrogen dalam semua senyawa organik adalah -III (Libes, 2009). Sebagian besar dari DON belum dikarakterisasi secara molekuler. DON meliputi urea, asam amino, zat humat, asam nukleat (DNA dan RNA), alkil dan amina kuartener. Selain itu, yang termasuk DON yaitu amida asal biologis, termasuk kitin, peptidoglikan dari dinding sel bakteri, $\quad \mathrm{N}$-acetylaminopolysaccharides ( $N$-AAPs), dan oligopeptida (Libes, 2009).

\section{Siklus Redoks Nitrogen}

Bilangan oksidasi nitrogen di laut menentukan reaksi redoks yang mengubah satu bentuk ke bentuk lain yang ditunjukkan pada Gambar 3. Beberapa proses transformasi nitrogen diantaranya asimilasi, fiksasi $\mathrm{N}_{2}$, dan remineralisasi (amonifikasi, oksidasi amonium, dan oksidasi nitrit). Selain itu, ada transformasi nitrogen yang terjadi secara anaerob diantaranya denitrifikasi dan oksidasi amonium anaerobik (Anammox). Pada proses denitrifikasi, nitrat digunakan sebagai akseptor elektron oleh bakteri heterotrof. Dalam proses anammox, amonium dan nitrit dikombinasikan untuk membentuk $\mathrm{N}_{2}$, melalui proses kimia sebagai berikut

$$
\mathrm{NO}_{2}^{-}+\mathrm{NH}_{4}^{+} \rightarrow 2 \mathrm{~N}_{2}+2 \mathrm{H}_{2} \mathrm{O}
$$

Reaksi Anammox digunakan sebagai sumber energi oleh bakteri kemoautotrof (Strous et al., 1999). 


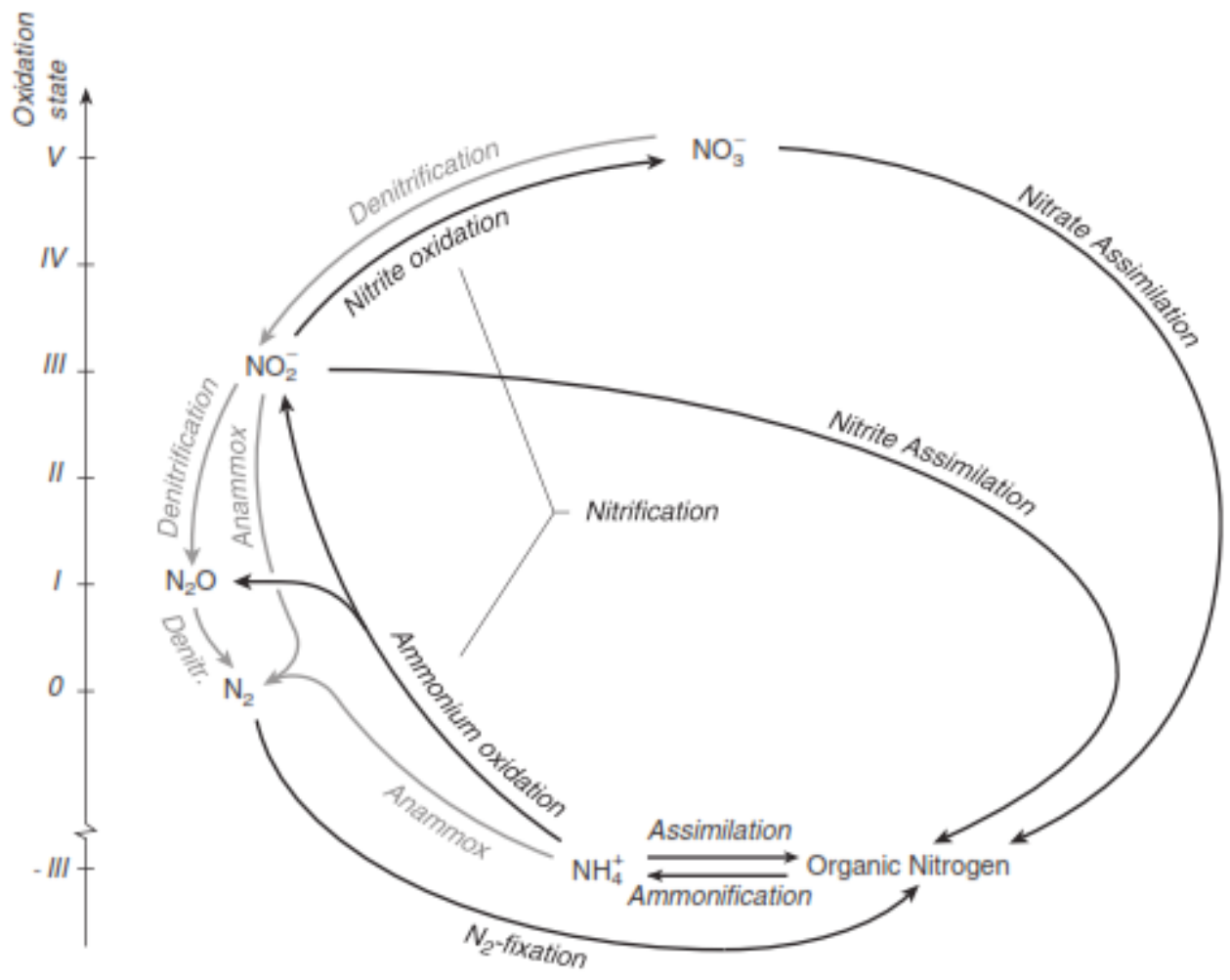

Gambar 3. Bentuk dan Transformasi Nitrogen di Laut (Gruber, 2008).

\section{Asimilasi Nitrogen Anorganik}

Asimilasi nitrogen anorganik yaitu transformasi nitrogen anorganik terlarut (amonium, nitrat, nitrit) menjadi nitrogen organik yang digunakan untuk kebutuhan fitoplankton (Libes, 2009). Amonium $\left(\mathrm{NH}_{4}^{+}\right)$diduga menjadi sumber yang disukai fitoplankton karena merupakan asimilasi yang tidak melibatkan reaksi redoks dan memerlukan sedikit energi (Zehr\&Ward, 2002). Oleh karenaitu, tidak mengherankan bahwa semua fitoplankton bisa memanfaatkan $\mathrm{NH}_{4}^{+}$sebagai satusatunya sumber nitrogen. Sebaliknya, asimilasi nitrat $\left(\mathrm{NO}_{3}^{-}\right)$melibatkan pengurangan nitrogen dari keadaan oksidasi +V ke -III, yaitu transfer delapan elektron, yang membutuhkan energi besar. Nitrat $\left(\mathrm{NO}_{3}^{-}\right)$di laut umumnya jauh lebih berlimpah dibandingkan $\mathrm{NH}_{4}^{+}$ dan sebagian besar fitoplankton memiliki enzim nitrat reduktase yang diperlukan untuk mereduksi ini. Organisme yang kurang memiliki kemampuan untuk menggunakan $\mathrm{NO}_{3}^{-}$sebagai sumber nitrogen adalah bakteri Prochlorococcus dan strain tertentu Synechococcus (Moore et al., 2002). Semua fitoplankton yang dapat menggunakan $\mathrm{NO}_{3}^{-}$, juga dapat menggunakan $\mathrm{NO}_{2}{ }^{-}$sebagai sumber nitrogen. Hal ini karena $\mathrm{NO}_{2}^{-}$merupakan produk perantara selama asimilasi $\mathrm{NO}_{3}{ }^{-}$ 
(Gruber, 2008). Namun, $\mathrm{NO}_{2}^{-}$biasanya hanya sumber yang sangat kecil dari nitrogen untuk fitoplankton, karena konsentrasinya lebih rendah dari $\mathrm{NO}_{3}^{-}$ atau $\mathrm{NH}_{4}^{+}$(Gruber, 2008).

Asimilasi nitrogen oleh fitoplankton sangat terkait dengan fiksasi fotosintetik karbon, karena kedua elemen ini diperlukan dalam rangka membangun jaringan hidup organik (Gruber, 2008). Hal yang sama juga berlaku untuk asimilasi fosfat. Kebanyakan fitoplankton memiliki kuota sel yang relatif tetap untuk protein, lipid, karbohidrat, dan DNA/RNA, sehingga cenderung untuk mengambil unsur-unsur yang berbeda dengan rasio yang relatif tetap (Hedges et al., 2002). Sintesis bahan organik dari $\mathrm{CO}_{2}, \mathrm{NO}_{3}^{-}, \mathrm{PO}_{4}^{3-}$ sebagai berikut:

$106 \mathrm{CO}_{2}+16 \mathrm{NO}_{3}^{-}+\mathrm{HPO}_{4}^{2-}+78 \mathrm{H}_{2} \mathrm{O}+$ $18 \mathrm{H}^{+} \rightarrow \mathrm{C}_{106} \mathrm{H}_{175} \mathrm{O}_{42} \mathrm{~N}_{16} \mathrm{P}+150 \mathrm{O}_{2}$

dan ketika $\mathrm{NH}_{4}^{+}$sebagai sumber nitrogen: $106 \mathrm{CO}_{2}+16 \mathrm{NH}_{4}^{+}+\mathrm{HPO}_{4}{ }^{2-}+48 \mathrm{H}_{2} \mathrm{O}+$ $14 \mathrm{OH}^{-} \rightarrow \mathrm{C}_{106} \mathrm{H}_{175} \mathrm{O}_{42} \mathrm{~N}_{16} \mathrm{P}+118 \mathrm{O}_{2}$

Selama proses asimilasi nutrien, DIN pertama aktif diangkut melintasi membran sel. Transportasi ini dimediasi oleh spesies enzim spesifik disebut permeases yang hadir dalam membran sel (Libes, 2009). Biomolekul nitrogen yang dihasilkan antara lain nukleotida (blok bangunan DNA / RNA dan pembawa energi NAD / NADP, ADP / ATP, FAD), gula amino (blok bangunan dari kitin dan peptidoglikan di dinding sel Bakteri), pigmen fotosintesis, vitamin, dan metabolit lainnya (Libes, 2009).

\section{Fiksasi Nitrogen}

Fiksasi nitrogen hanya ditemukan di lingkungan yang memiliki konsentrasi nitrogen reaktif rendah. Seperti yang ditunjukkan oleh stoikiometri berikut, bahwa delapan elektron dan 16 molekul ATP diperlukan untuk mengurangi satu molekul N $\mathrm{N}_{2}$ (Libes, 2009)

$$
\begin{aligned}
& \multicolumn{2}{c}{\text { nitrogenase }} \\
& \mathrm{N}_{2}+8 \mathrm{H}^{+}+8 \mathrm{e}^{-}+16 \mathrm{Mg} \text { ATP } \rightarrow 2 \mathrm{NH}_{3} \\
& +\mathrm{H}_{2}+16 \mathrm{MgADP}+16 \mathrm{P}_{\mathrm{i}}
\end{aligned}
$$

Dalam reaksi ini ikatan rangkap tiga $\mathrm{N}$ terpecah dan atom nitrogen mengalami reaksi anabolik dalam biomolekul. Enzim yang diperlukan untuk fiksasi nitrogen disebut nitrogenase. Besi merupakan kofaktor utama yang diperlukan dalam jumlah besar dan merupakan faktor pembatas dalam fiksasi nitrogen (Libes, 2009).

\section{Pelarutan dan Amonifikasi}

Perubahan nitrogen organik menjadi nitrogen anorganik melalui serangkaian reaksi mediasi mikroba. Langkah pertama dalam proses ini adalah pelarutan dan amonifikasi. Amonifikasi dilakukan oleh bakteri, Actinomycetes dan jamur untuk mengubah $\mathrm{N}$ organik (seperti yang ditemukan dalam protein, gula, amino, asam nukleat) menjadi amonium anorganik (Herbert, 1999).

Proses perubahan PON (Particulate Organic Nitrogen) melibatkan degradasi senyawa organik selama karbon teroksidasi, dan tidak 
mengalami perubahan dalam reaksi redoks. Pertama, PON diurai menjadi DON oleh fragmentasi biomolekul menjadi senyawa lebih sederhana. Gambar 4 menggambarkan degradasi protein melalui kerusakan ikatan karbonnitrogen antara unit asam amino yang berdekatan, dan proses ini menghasilkan oligopeptida dengan kelompok amina terminal. Degradasi yang terus menerus akhirnya mengakibatkan kerusakan dari ikatan karbon-nitrogen pada amina terminal ini, sehingga melepaskan nitrogen ke dalam air laut sebagai amonia $\left(\mathrm{NH}_{3}\right)$. Amonia ini bereaksi dengan $\mathrm{H}^{+}$ atau $\mathrm{H}_{2} \mathrm{O}$ untuk membentuk amonium $\left(\mathrm{NH}_{4}^{+}\right)$(Libes, 2009).

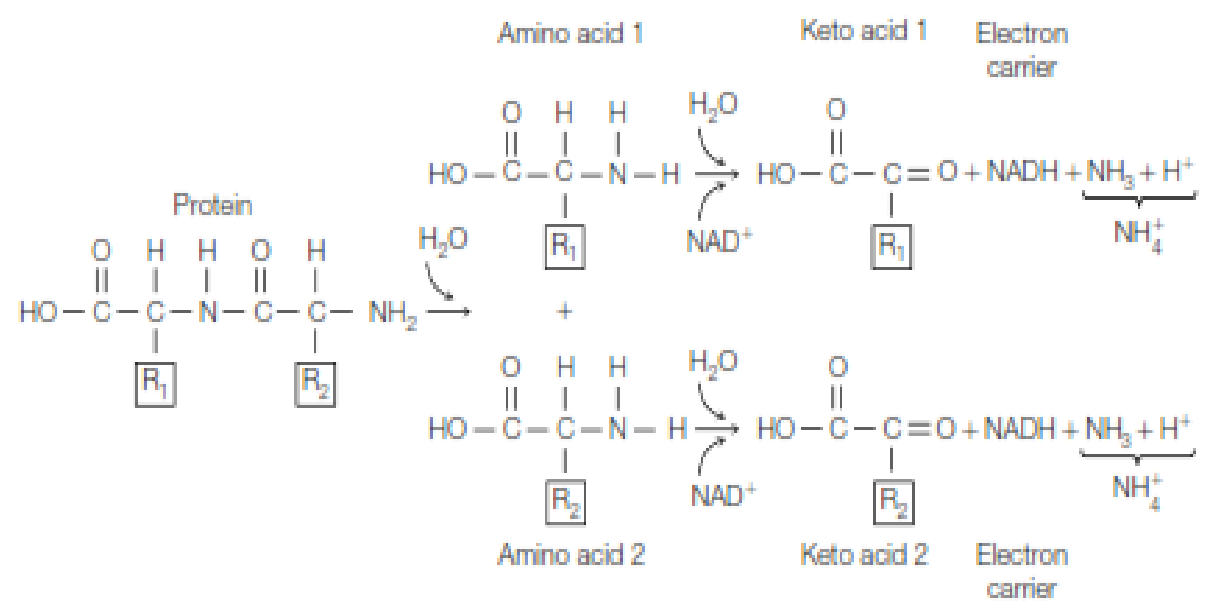

Gambar 4. Proses Amonifikasi (Libes, 2009).

\section{Oksidasi Amonium}

\section{Nitrifikasi}

Nitrifikasi adalah proses perubahan amonia menjadi nitrat, melalui dua langkah proses aerobik. Langkah pertama adalah oksidasi amonia menjadi nitrit dan langkah kedua nitrit teroksidasi menjadi nitrat (Voss, 2011). Energi yang diperoleh dari oksidasi amonium dan nitrit digunakan untuk bahan bakar proses metabolisme termasuk fiksasi dari $\mathrm{CO}_{2}$ menjadi karbon organik. Bakteri yang mengoksidasi amonia menjadi nitrit yaitu Nitrosomonas, Nitrosospira, Nitrosococcus, dan Nitrosolobus sedangkan bakteri yang mengoksidasi nitrit menjadi nitrat yaitu Nitrobacter, Nitrosospina, Nitrocystis, dan Nitrococcus (Libes, 2009).

Tahapan dari nitrifikasi selama dekomposisi aerobik detrital PON diilustrasikan pada Gambar 5. Awalnya, degradasi PON menghasilkan amonium, yang merangsang pertumbuhan oksidasi nitrat. Bakteri ini mengubah amonium menjadi nitrit, menyebabkan konsentrasi amonium menurun dan konsentrasi nitrit meningkat. Tingkat kenaikan nitrit merangsang pertumbuhan nitrit yang dioksidasi. Bakteri ini mengubah nitrit menjadi nitrat, dan akhirnya semua DIN teroksidasi menjadi nitrat (Libes, 2009). 


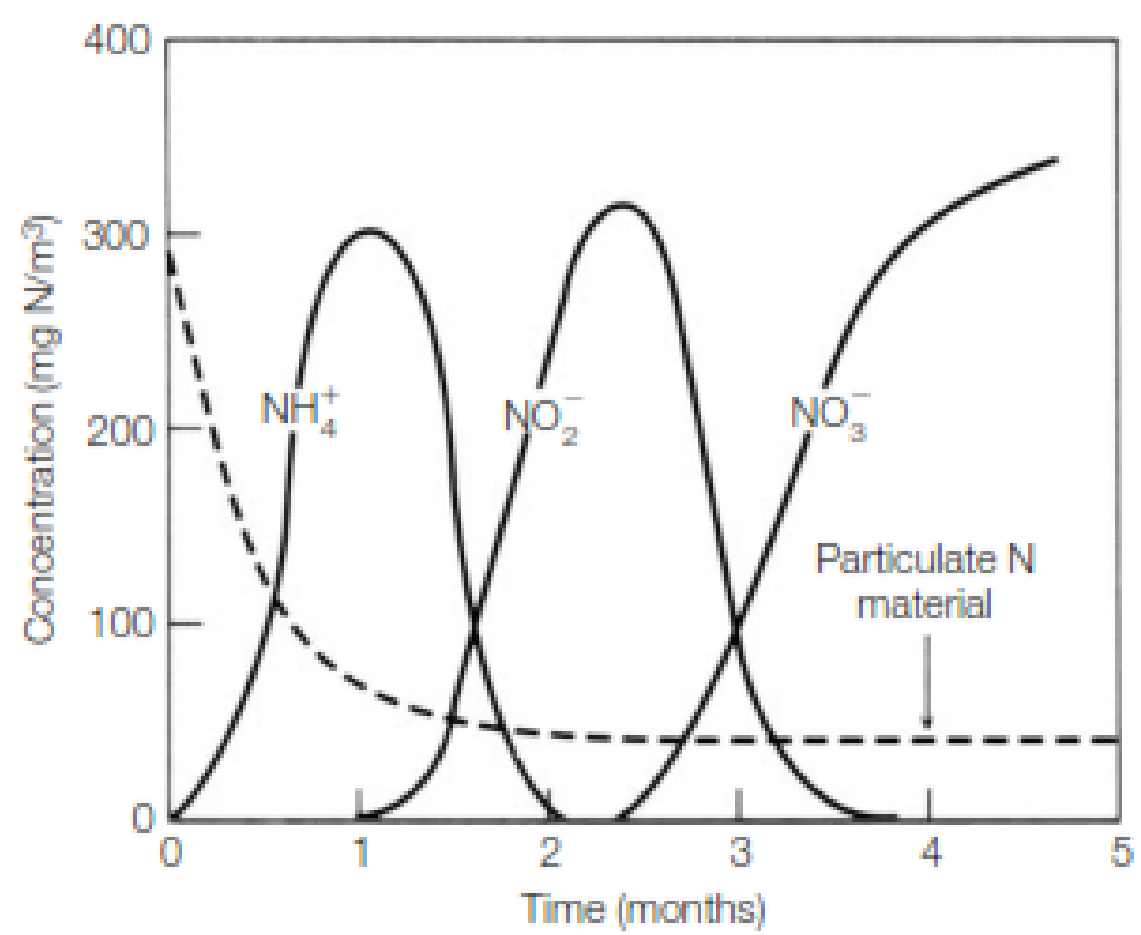

Gambar 5. Produksi Material Nitrogen dari dekomposisi fitoplankton (Libes, 2009).

Nitrifikasi membutuhkan kehadiran dari oksigen dan cenderung dihambat oleh cahaya, yang memiliki implikasi penting siklus nitrogen laut di atas. Dua proses dari nitrifikasi aerobik yaitu oksidasi amonium dan oksidasi nitrit (Gruber, 2008), melibatkan proses kimia sebagai berikut:

$2 \mathrm{NH}_{4}^{+}+3 \mathrm{O}_{2} \rightarrow 2 \mathrm{NO}_{2}^{-}+4 \mathrm{H}^{+}+2 \mathrm{H}_{2} \mathrm{O}$

$2 \mathrm{NO}_{2}^{-}+\mathrm{O}_{2} \rightarrow 2 \mathrm{NO}_{3}^{-}$

\section{Oksidasi Amonium Anaerobik dan Denitrifikasi}

Amonium sering terakumulasi dalam konsentrasi cukup tinggi di sedimen anoksik dan di perairan yang konsentrasi oksigennya sangat rendah (Capone et al., 2008). Amonium dapat teroksidasi oleh mikroba dalam kondisi anaerob dalam kolom air dan sedimen. Dalam reaksi Anammox (Anaerobic Ammonium Oxidation), bakteri mengoksidasi amonium menjadi gas nitrogen menggunakan nitrit sebagai akseptor elektron. Proses ini sebenarnya bentuk denitrifikasi, karena fungsinya adalah untuk menghilangkan bentuk $\mathrm{N}$ tetap (Libes, 2008; Capone et al., 2008).

Denitrifikasi adalah satusatunya proses yang permanen untuk menghilangkan nitrogen reaktif dari lingkungan air dan darat. Denitrifikasi adalah proses reduksi nitrat menjadi gas 
$\mathrm{N}_{2}$ sebagai produk akhir dan $\mathrm{N}_{2} \mathrm{O}$ sebagai perantara. Tingkat proses ini sangat dikendalikan oleh suhu, konsentrasi nitrat dan ketersediaan karbon organik (Hulth et al., 2004).

Tabel 2. Proses Transformasi Nitrogen di Laut (Gruber, 2008)

\begin{tabular}{|l|l|l|l|}
\hline \multicolumn{1}{|c|}{ Proses } & \multicolumn{1}{|c|}{ Organisme } & \multicolumn{1}{c|}{$\begin{array}{c}\text { Lingkungan } \\
\text { redoks }\end{array}$} & \multicolumn{1}{c|}{ Status trofik } \\
\hline Asimilasi $\mathrm{NO}_{3}^{-}$ & Fitoplankton & Aerob & Fotoautotrof \\
\hline Asimilasi $\mathrm{NO}_{2}^{-}$ & Fitoplankton & Aerob & Fotoautotrof \\
\hline Asimilasi $\mathrm{NH}_{4}^{+}$ & Fitoplankton & Aerob & Fotoautotrof \\
\hline & Bakteri & Aerob/anaerob & Heterotrof \\
\hline Amonifikasi & Bakteri/Zooplankton & Aerob/anaerob & Heterotrof \\
\hline Oksidasi $\mathrm{NH}_{4}^{+}$ & $\mathrm{NH}_{4}^{+}$oxidizers & Aerob & Kemoautotrof \\
\hline & $($ Nitrosomonas $)$ & & \\
\hline Oksidasi $\mathrm{NO}_{2}^{-}$ & $\mathrm{NO}_{2}^{-}$oxidizers & Aerob & Kemoautotrof \\
\hline & $($ Nitrobacter $)$ & & \\
\hline Denitrifikasi & Bakteri & Anaerob & Heterotrof \\
\hline Anammox & Bakteri & Anaerob & Kemoautotrof \\
\hline Fiksasi $\mathrm{N}_{2}$ & Cyanobakteri & Aerob & Fotoautotrof \\
\hline & $($ Trichodesmium $)$ & & \\
\hline
\end{tabular}

\section{PENUTUP}

Nitrogen merupakan elemen yang sangat berperan di bumi. Di dalam air laut nitrogen sebagian besar berbentuk sebagai gas $\mathrm{N}_{2}$ terlarut tidak reaktif, sehingga nitrogen perlu mengalami transformasi menjadi bentuk anorganik untuk dapat digunakan oleh fitoplankton. Akhir-akhir ini terjadi peningkatan emisi nitrogen ke laut, sehingga menyebabkan ketidakseimbangan siklus nitrogen. Jumlah nitrogen yang terus meningkat terutama disebabkan oleh aktivitas manusia. Jika hal ini dibiarkan terus berlanjut maka akan terjadi eutrofikasi yang menimbulkan ketidakseimbangan dalam ekosistem.

\section{DAFTAR PUSTAKA}

Beman, J.M., K.R. Arrigo, and P.A. Matson. 2005. Agricultural run off fuels large phytoplankton blooms in vulnerable areas of the ocean. Nature 434: 211-214. 
Canfield, D.E., A.N. Glazer, and P.G. Falkowski. 2010. The Evolution and Future of Earth's Nitrogen Cycle. Science 330: 192 -196.

Capone, D.G., D.A. Bronk, M.R. Mulholland, and E.J. Carpenter. 2008. Nitrogen In The Marine Environment. 2nd Edition. Academic Press: 199-261.

Cugier, P., G. Billen, J.F. Guillaud, J. Garnier, and A. Ménesguen. 2005. Modelling the eutrophication of the Seine Bight (France) under historical, present and future riverine nutrient loading. Journal of Hydrology 304: $381-396$.

Duce, R.A., J. LaRoche, K. Altieri, K.R. Arrigo, A.R. Baker, D. G. Capone, S. Cornell, F. Dentener, J. Galloway, R. S. Ganeshram, R.J. Geider, T. Jickells, M.M. Kuypers, R. Langlois, P.S. Liss, S. M. Liu, J.J. Middelburg, C.M. Moore, S. Nickovic, A. Oschlies, T. Pedersen, J. Prospero, R. Schlitzer, S. Seitzinger, L. L. Sorensen, M. Uematsu, O. Ulloa, M. Voss, B. Ward, and L. Zamora. 2008. Impacts of atmospheric anthropogenic nitrogen on the open ocean . Science 320: 893-897.
Galloway, J.N., F.J. Dentener, D.G. Capone, E.W. Boyer, R.W. Howarth, S.P. Seitzinger, G.P. Asner, C.C. Cleveland, P.A. Green, E. A. Holland, D.M. Karl, A.F Michaels, J.H. Porter, A.R. Townsend and C.J. Voosmarty. 2004. Nitrogen cycles: past, present, future. Biogeochemistry (70): 153226.

Gruber, N. 2008. The Marine Nitrogen Cycle: Overview and Challenges. Nitrogen in the Marine Environment. Elsevier Inc. 50pp

Hedges, J.I., J. Baldock, Y. Gelinas, C. Lee, M. Peterson and S. Wakeham. 2002. The biochemical and elemental compositions of marine plankton: A NMR perspective. Mar. Chem. 78(1): 47-63.

Herbert, R.A. 1999. Nitrogen cycling in coastal marine ecosystems. Microbiology Reviews, 23: $563-590$.

Hulth, S., R.C. Aller, D.E. Canfield, T. Dalsgaard, P. Engstrom, F. Gilbert, K. Sundback and B. Thamdrup. 2004. Nitrogen removal in marine environments: recent findings and future research challenges. Marine Chemistry 94: 125-145. 
Karlson, K., E. Bonsdorff and R. Rosenberg. 2007. The impact of benthic macrofauna for nutrient fluxes from Baltic Sea sediments . Ambio 36: $161-167$.

Lancelot, C., N. Gypens, G. Billen, J. Garnier, and V. Roubeix. 2007. Testing an integrated river-ocean mathematical tool for linking marine eutrophication to land use: the Phaeocystis-dominated Belgian coastal zone (Southern North Sea) over the past 50 years . Journal of Marine Systems 64: 216 -228 .

Libes, S. 2009. Introduction to Marine Biogeochemistry. Second Edition. Academic Press, 925pp.

Moore, L.R., A. F. Post, G. Rocap, and S.W. Chisholm. 2002. Utilization of different nitrogen sources by the marine cyanobacteria prochlorococcus and synechococcus. Limnol. Oceanogr. 47(4): 989-996.
Strous, M., J. A. Fuerst, E. H. M. Kramer, S. Logemann, G. Muyzer, K. T. van de Pas-Schoonen, R. Webb, J.G. Kuenen, and M.M. S. Jetten. 1999. Missing lithotroph identified as new planctomycete. Nature 400: 446-449.

Voss, M. 2011. Nitrogen processes in coastal and marine ecosystems. The European Nitrogen Assessment. Cambridge University Press: 147-176.

Voss, M., H.W. Bange, J.W. Dippner, J.J. Middelburg, J.P. Montoya and B.Ward. 2013. The marine nitrogen cycle: recent discoveries, uncertainties and the potential relevance of climate change. Phil Trans $R$ Soc B 368:20130121.

Zehr, J.P., and B. B. Ward. 2002. Nitrogen cycling in the ocean: New perspectives on processes and paradigms. Appl. Environ. Microbiol. 68(3): 1015-1024. 